\title{
Decentralized School Based Governance Structures and Fiscal Decision-Making in Hawassa University Technology Village Public Secondary Schools; Policy - Practice Concordance
}

\author{
Fitsum Gebremichael Solomon (M.A) \\ Lecturer, Department of Educational Planning and ManagementCollege of EducationHawassa \\ UniversityHawassa, Ethiopia
}

\begin{abstract}
The main purpose of this study was to investigate the decentralized secondary school governance structures, fiscal decision-making and the implications to school improvement activities in public secondary schools of Hawassa University technology village sites. To this end, descriptive study method was employed and primary and secondary sources of data were used. The study was conducted in five randomly selected public secondary schools of Hawassa university technology village sites that were drawn from a total of ten public secondary schools found in the study site. The primary data from deputy principals and teacher representatives in the school board were gathered through questionnaire. For this purpose thirty one questionnaires were distributed to the respondents and properly filled and returned. In addition five school principals were interviewed. Secondary data were secured through document consultation of relevant materials from MoE, SNNP regional education bureau, Sidama Zone education bureau. The data obtained from the questionnaires were analyzed using quantitative statistical tools such as percentages, mean, independent t-test. Moreover, the primary data gathered through interview were analyzed qualitatively in a narration mode so as to substantiate the quantitative values analyzed from the questionnaire. Finally the findings indicated that the school boards were established with top-down initiative of the ministry of education, the composition of the school board did not show academic preparation for the assignment, limited number of school level stakeholders in the school board membership, irregularity of the school board meeting and decision-making, lack of consistency in the utilization of school funds, absence of monitoring of financial decision implementation by the school boards. Hence, it is concluded that, the school board establishments lacked bottom-up initiatives, political and party engagement consideration in the selection of school board members influenced the professional decision-making of the boards, delayed board meetings affected timely financial decisions, irregularities among the schools in the fund endorsement. On the basis of this findings and conclusions, rearrangement of school board composition, reconsideration of the members assignment criteria, enhanced role of school board in monitoring financial decisions implementation,, involvement of the community in periodical discussion forums on school plans and budget implementation, organizing workshops on the endorsement and release, utilization of school funds were recommended for the ministry of education, SNNP regional education bureau, Sidama Zone education bureau and the woreda education departments.
\end{abstract}

Key words: Decentralized Governance Structures, Fiscal Decision-making, School Based Management

\subsection{Background of the Study}

\section{INTRODUCTION}

Governments around the world are introducing a range of strategies aimed at improving the financing and delivery of education services, and recently they have an emphasis on improving quality as well as increasing quantity (in terms of enrollment rates). The decentralization of educational decision making is one such strategy. Advocates of this strategy maintain that decentralizing decision making encourages demand for a higher quality of education and ensures that schools reflect local priorities and values (Barrera-Osori etal,2009)There is currently a global trend towards the decentralizing of education systems. Most countries are experimenting or contemplating some form of decentralization. Proponents of education decentralization claim that "reorganization will improve the quality of teaching and learning by locating decisions closer to the point at which they must be carried out and be energizing teachers and administrators to do a better job"(Fiske 1996, p. 24). Although the impact of education decentralization has been analyzed in the literature for nearly fifteen years, there is still no consensus on whether these policies positively impact education output and schooling.

Decentralized education delivery, moving decision-making closer to the needs of each school and finding the right balance of centralized and decentralized responsibilities will improve education provision by focusing more on cultural differences and learning environments. In addition, it will improve accountability by giving incentives for quality performance to teachers and school officials (HanushekandRivkin2003).Similarly, 
closer parent-school partnership through decentralization can improve both the school and home environment to learning.By giving a voice and decision-making power to local stakeholders who know more about the local educational systems than do central policy makers can improve educational outcomes and increase client satisfaction. One way to decentralize decision-making power in education is known popularly as school-based management (Barrera-Osori etal,2009)

School based management refers to the decentralization of authority from the central government to the school level.SBM (school based management) emphasizes the individual school (represented by any combination of principals, teachers, parents, students, and other members of the school community) as the main decision-making authority, and holds that this shift in the formulating of decisions would lead to improvement in the delivery of education (Barrera-Osori etal,2009)According to Barrera-Osori etal, (2009) the term school based management defined as "A formal alteration of governance structures, as a form of decentralization that identifies the individual school as the primary unit of improvement and relies on the re-distribution of decisionmaking authority as the primary means through which improvement might be stimulated and sustained.

SBM programs take many different forms in terms of who has the power to make decisions and how much decision-making authority devolved to the school level. Some programs transfer authority only to school principals or teachers, others encourage or mandate parental and community participation, often through their active membership in school committees (Barrera-Osori etal, 2009). Administrative control (the principal is dominant); professional control (teachers are dominant); community control (parent/community dominates) and balanced control (parents and professional are equals)In general, SBM programs devolve authority over one or more activities. These can be any of the following: budget allocation, hiring and firing of teachers and school staff, curriculum development, procurement of text books and other educational materials, infrastructure improvement and monitoring and evaluation of teacher performance and student learning outcomes (BarreraOsori etal, 2009).SBM reforms are far from uniform and they encompass a wide variety of strategies. Each program is shaped by the objectives of the reformers and by the broader national policy and social context in which it is created. There are two key dimensions to the devolution of decision-making. These are the degree of autonomy being devolved, and the people to whom the decision-making is devolved. With so many possible combinations of these two dimensions, almost every SBM reform is unique. It is estimated that there are more than 800 SBM models in the United States alone and globally the SBM reforms vary even more widely. Different SBM reforms are underway in Africa. Some of the earlier efforts were conceived under the umbrella of "whole school development", a package of reforms aimed at improving school management, in-service training and monitoring and evaluation (Barrera-Osori etal, 2009).There are four models that typify the various arrangements included in SBM reforms. These are administrative-control, professional-control, communitycontrol and balanced-control. Administrative-control is authority devolved to school principal; professionalcontrol is which teachers hold decision-making power, community-control gives authority to the parents and balanced-control is by which decision-making authority is shared by parents and teachers.

In understanding education governance, it is very crucial to analyze autonomy-participationaccountability nexus. In running schools, people who make decisions needed to be empowered and accountable to adhere rules and standards, their peers, students learning and the general public. This leads further increase transparency of the decision-making process. Consequently, students' learning achievements and other outcomes can be expected to be improved because stakeholders at the school level can monitor school personnel, work to improve students' evaluation, ensure a closer match between schools needs and policies, and the use of resources more efficiently (Barrera-Osori etal, 2009).

Decentralization of finance arguments are a recent phenomenon. The proportion of school age children enrolled in the primary and secondary schools has grown rapidly over the past two decades, and educational expenditures have grown rapidly as well. Central governments now find themselves facing sever fiscal constraints to continued expansion of educational opportunities. Hence, shifting part of the burden for support of primary and secondary education to sub national units of government, community and voluntary organizations, and to parents has become an increasingly attractive alternative. The form of shifting advocated in decentralization plans varies with a variety of country characteristics, including the form of government, traditions of community involvement. The efficiency rationale for decentralization argues that centralized planning and administration, both at the national level and in large urban school districts have resulted in expensive education, which is decreasing in quality(Hannaway and Carnoy,1993). In district-school relationship genuine decentralization of authority and responsibility to the local school within a framework designed to assure school-to-school equity and a measure of accountability (Brown, 1990).

The Ethiopian education and training policy issued in 1994 stipulated that education management becomes decentralized to create the necessary condition to expand, enrich and improve the relevance, quality, accessibility and equity of education and training. Educational institutions become autonomous in their internal administration and in the designing and implementing of education and training programs, with an overall coordination and democratic leadership by boards or committees, consisting of members from the community, 
development and research institutions (TGE, 1994)The financial system of education in Ethiopia is decentralized not only because it is the best option from the point of view of financial management, but also because it has been established to build a democratic system in the country based on popular participation only when power is adequately shared with the lower hierarchies of the administration (MoE, 2006).

\subsection{Statement of the Problem}

The inadequate funding of local government since decentralization demands a rather heavy burden of community participation to support schools. There are no clear guidelines for communities' role and many communities lack information which creates weak link of citizen participation in the service delivery chain (MoE,2006)

A tendency is observed by the educational officials that the woreda councils(province councils) tend to keep the schools budget and process procurements on behalf of the schools with the rationale that the latter have no capacity. Thus the research investigates on top of these situations. Therefore, it assessed the governance structure found in the schools like Woreda Education and Training Boards (WETB).In line to school based governance structures the research investigates on their autonomy, accountability and participation in accordance with fiscal decision-making and their implications to school improvement activities. In doing so the research will attempt to answer the following basic questions;

1. To what extent the decentralized school- based governance structures organized in the public secondary schools?

2. How are the fiscal decisions being undertaken under the school based decentralized structures of the public secondary schools?

\subsection{Objectives of the Study}

1.3.1 General Objective

To assess decentralized School Based Governance Structures and Fiscal Decision-making and their implications to School Improvement in Hawassa University Technology Village Public Secondary School

1.3.2. Specific Objectives

The study will have the following specific objectives

$>$ To identify how the decentralized schools based governance structures are organized in the public secondary schools

$>$ To describe how the fiscal decisions are being undertaken under the school based decentralized structures of the public secondary schools

\section{MATERIALS AND METHODS}

\subsection{Description of the Study Area}

The study was conducted in the selected public secondary schools found in Hawassa University technology Village sites. Five public secondary schools were selected from from Sidama Zone woredas namely; Wondo Genet, Yigalem, Aposto,Leku and Aleta Wondo.

\subsection{Study subject}

The study investigated on the decentralized secondary school governance structures, fiscal decision-making. In doing so the research targeted on school principals, teachers and parents involved in school level decisionmaking positions like school board (Woreda Education and Training board), parent teacher associations.

\section{3 study design}

The study investigated about the relationship between decentralized school based governance structures, fiscal decision-making. In line to this situation, descriptive study had been selected as the study design as it describes and interprets what is. It is concerned with the conditions or relationships that exist, opinions that are held, processes that are going on, effects that are evident, or trends that are developing(Best and Kahan,2005).

\subsection{Population, Sample and Sampling Techniques}

Table 1 Population and Sampling of secondary schools

\begin{tabular}{|l|l|l|l|}
\hline No & Name of the School & Respondents \\
\cline { 3 - 4 } & & Frequency & Percentage \\
\hline 1 & Aleta Wondo Secondary School & 4 & $12.9 \%$ \\
\hline 2 & Aposto Secondary School & 7 & $22.6 \%$ \\
\hline 3 & Leku Secondary School & 5 & $16.1 \%$ \\
\hline 4 & Wondo Genet Secondary School & 7 & $22.6 \%$ \\
\hline 5 & Yirgalem Secondary School & 8 & $25.8 \%$ \\
\hline & Total & 31 & $100 \%$ \\
\hline
\end{tabular}


As it indicated in table 1, the research was targeted on the Hawassa University Technology site public schools. Accordingly, the researcher selected one secondary school from each of the five woredas and city administrations. Thus, out of the population of ten public secondary schools, samples of five secondary schools were selected by random sampling technique. The sample schools covered $50 \%$ of the total populations of secondary schools.In the selected sample secondary schools all of the principals $5(100 \%)$ and all of the available teachers and parents who were members of the school board, parent teacher association, were selected purposively by using availability sampling technique.

\subsection{Study methodology}

In order to achieve the research objectives, both primary and secondary sources of data were collected from the relevant data sources. The primary data was gathered from school principals, parents, teachers who were members of school board. In-depth interviews were conducted with Principals and parents. Questionnaire was used to collect data from deputy principals and teachers who were representatives in the education and training boards. Secondary data like school strategic plans, school board meeting minutes, PTA and, School improvement committees' minutes and other pertinent policy and strategic and resource management directives and documents were be consulted to support the research analysis.

\subsection{Research Variables, Data Management and Analysis}

The study has two independent variables; decentralized school based governance, school fiscal decision-making. The dependent variable is school improvement. The research questions are designed to assess the relationship between these variables. So as to respond to these research questions both qualitative and quantitative methods of data analysis were used in the research investigation.In order to validate and undertake some necessary corrections and modifications on the questionnaires as well as to reduce practical problems in advance, pilot testing was undertaken before the actual distribution of questionnaires and conducting interviews. Thus, one secondary school out of the already selected sample schools was taken. Then $5 \%$ of the respondents were given the questionnaires and interview questions were conducted. Then ambiguous and unclear statements were corrected and tool validity and reliability were checked by using the relevant statistical tests. The qualitative data obtained from the interviews and open ended questions of the questionnaires, document analysis were analyzed using narration mode as expressed by the respondents and as understood by the researcher. Quantitative data gathered through questionnaires was analyzed by using statistical techniques like central tendency measures like percentages, mean values to check the respondents' frequency of responses and inferential statistics such as independent t-test were calculated by using SPSS version 20 to investigate the significance relationships found between the dependent and independent variables.

\section{RESULT AND DISCUSSION}

This chapter of the study deals with result and discussion of the collected and analyzed data from the sample respondents. The primary data were obtained through questionnaire, interview and interpreted in accordance with the basic questions.

\subsection{Characteristics of the Respondents}

The purpose of this section is to provide some basic background information about the characteristics of the sample respondents of the study.

Table 2 School Board Teacher Representatives Educational Qualification and Service Years

\begin{tabular}{|l|l|l|l|}
\hline $\mathbf{N o}$ & Respondents Sex & Frequency & Percentage \\
\hline 1 & Male & 28 & $90.3 \%$ \\
\hline 2 & Female & 3 & $9.7 \%$ \\
\hline $\mathbf{N o}$ & Total & 31 & $100 \%$ \\
\hline $\begin{array}{l}\text { Respondents } \\
\text { Educational } \\
\text { Qualification }\end{array}$ & Frequency & Percentage \\
\hline 1 & College Diploma & 2 & $6.7 \%$ \\
\hline 3 & B.A/B.Sc & 26 & $86.7 \%$ \\
\hline & M.A/M.Sc & 2 & $6.7 \%$ \\
\hline & Total & 30 & $100 \%$ \\
\hline 1 & $\begin{array}{l}\text { Respondents } \\
\text { Work Experience }\end{array}$ & Frequency & Percentage \\
\hline 2 & $\leq 5$ Years & 2 & 6.7 \\
\hline 3 & 6-10 Years & 4 & 13.3 \\
\hline 4 & 11-15 Years & 9 & 30.0 \\
\hline 5 & $16-20$ Years & 5 & 16.7 \\
\hline & $\geq 21$ Years & 10 & 33.3 \\
\hline
\end{tabular}


In the study a total of 31 questionnaires were filled by teachers and deputy principals who were representatives in the woreda education and training boards of the schools. In-depth interviews were conducted with five school principals that were working as secretaries of the school boards and ten parents who were members of the school boards.As the table 2 above shows, majority 28(90.3\%) of the teacher representatives in the education and training boards of the sample schools were males and the remaining $3(9.7 \%)$ of them were females.Concerning the educational qualification of the teachers representatives of the school boards,2(6.7\%) of the respondents were college diploma holders, 2(6.7\%) were qualified with bachelor degrees26(86.7\%) and $2(6.7 \%)$ were masters degree holders. The result reveals that majority of the respondents were bachelor degree holders. As the table describes below about the service years of the teacher representatives in the board,2(6.7\%) had less than five years work experience,4(13.3\%) of them were with 6-10 years of service,9(30.0\%) had 11-15 years of work experience, $5(16.7 \%)$ were with 16-20 years of work experience and the rest of the respondents that is $10(33.3 \%)$ had more than twenty one years of work experience.

\subsection{Decentralized school governance structures}

The aim of this sub-section is to make thorough discussions and interpretation on school governing boards. Thus it focuses on the themes such as the presence of education and training boards in the schools, board members; composition, understanding of their roles, members academic and professional preparation, how the school boards were established, the frequency of conducting board meetings and the respondents roles. In addition, this part makes explanations on the school boards mandate in exercising decision-making power in their schools.

Table 3 Decentralized School Governance Structures

\begin{tabular}{|c|c|c|c|c|c|c|c|c|}
\hline \multirow{2}{*}{$\begin{array}{l}\mathbf{N} \\
\underline{\mathbf{o}}\end{array}$} & \multirow[t]{2}{*}{ Variables } & \multicolumn{2}{|c|}{ Yes } & \multicolumn{2}{|l|}{ No } & \multirow[b]{2}{*}{ Mean } & \multicolumn{2}{|c|}{ t-test Statistics } \\
\hline & & Freq & Percent & $\begin{array}{l}\text { Fre } \\
\text { q }\end{array}$ & Percent & & $\mathbf{t}$ & P-value \\
\hline 1 & Availability of School governing board & 31 & $100 \%$ & 0 & 0 & & & \\
\hline 3 & $\begin{array}{l}\text { Members of the board have professional and } \\
\text { academic preparation to assume their duties }\end{array}$ & 21 & $67.7 \%$ & 10 & $32.3 \%$ & 1.3226 & 15.497 & 0.000 \\
\hline
\end{tabular}

As item 1 of table 3 indicates, the entire teacher representatives suggested that their schools were being governed by an established education and training boards. In an interview conducted on the secondary school board composition, secondary school principal stated as follows; In my school, the school board chairperson is the head of the town municipality and three members are parents selected from Parent Teacher Association of the school. I am the principal of the school serve as the board secretary. In addition, in the government there is a prescribed directive that youth and women representatives are included in the school boards from the youth league and women association found in the town. However, in our school youth and women representatives have not been incorporated in school board so far. There is a plan to include them. Due to the absence of these two representatives the board had six members.In another interview made with a secondary school principal. He stated the following about his school board;Our school board comprises of eleven members and its different from the usual seven to nine members of a secondary school board composition that commonly exists in most secondary schools. In our case the additional number of members representation in the school is due to the deputy principals included as non-voting members made to be available to deliver briefings on school plan and budget designed by the school management for clear endorsement and support the approval decisions by the board members.

Another secondary school principal justified the board composition in the following statement during the interview; In addition, to the above reasons, our school has about 5,000 students. This large number of students demanded the school administrative structure to include five deputy principals despite the common two deputy principals found in most secondary schools.Decentralized structures, and allow a progressive devolution of powers. Ones these conditions are brought together, measures for decentralizing financial decision-making power and education management which are encouraged and supported by central governments should allow the African education systems to continue expanding while upgrading performance ( UNESCO/IIEP1999).Regarding the school board members understanding of their roles, 28(90.3\%) of the respondents and mean value 1.0968 stated that the members had certain understanding on their roles and responsibilities expected while governing their schools. The t-test statistics calculated to investigate the relationship between school boards' members understanding of their roles and duties in board and improvement achieved on the students learning and academic achievement with t value of 20.319 and p-value from this statistics was 0.000 and that was less than 0.05 (the level of significance usually used for the test) such a p-value showed that there was statistically significant relationship between school boards' members understanding of 
their roles and duties in board and improvement achieved on the students learning and academic achievement .One of the interviewed principal stated about the board members understanding of their roles as follows;

Most of the school board members' representation seems more of assignment based on political party and ethnic affiliation. I believe there is little emphasis being given to their academic preparation and awareness about school operations. In some cases, members do not come for the regular meetings due to their party and political engagements in the community mobilization. In addition, they are not as such ready and interested to involve in school board issues without any monetary incentives. These hamper our timely strategic decision making and implementation of school activitiesIn addition one secondary school principal stated the situation as follows;

There were several times when the school board meetings conducted in the absence of youth and women league representatives. One of the big problems in our school board is the frequent absence of board chairperson due to his engagement in the political and multi-sector town administration duties and responsibilities. Sometimes I feel that its better not to select government officials and politicians as board chairperson as they are are very busy of their office positions and other political assignments that make them hardly avail at school.

Concerning board members professional and academic preparation, 21(67.7\%) of the representatives and the calculated mean value 1.3226 indicated that the members have better professional and academic preparations to assume the task of leading the school boards. The t-test statistics calculated to investigate the relationship between school boards' members professional and academic preparation to assume the boards' duties and responsibilities and improvement brought on the students learning and academic achievement with $t$ value of 15.497 and p-value from this statistics was 0.000 and that was less than 0.05 (the level of significance usually used for the test) such a p-value showed that there was statistically significant relationship between school boards' members professional and academic preparation to assume the boards' duties and responsibilities and improvement brought on the students learning and academic achievement.

Pertaining the composition of the school board members and their mandate in exercising decisionmaking, $30(100 \%)$ and $28(93.3 \%)$ of the respondents indicated that the boards had balanced representation in their membership and they exercised real power in governing the schools respectively. The t-test statistics calculated to investigate the relationship between school boards' members composition and balanced representation from school stakeholders and improvement brought on the students learning and academic achievement with $t$ value of 21.762 and p-value from this statistics was 0.000 and that was less than 0.05 (the level of significance usually used for the test) such a p-value showed that there was statistically significant relationship between school boards' members composition and balanced representation from school stakeholders and improvement brought on the students learning and academic achievement. In an interview conducted with a principal of a senior secondary school he indicated the following about school board composition;

My school board does not have limited term of office. Conventionally it is believed that the board functions similar to a five year one term of regional government term of office. The chairperson as a mayor and government official he serves in the board as long as he is politically appointed and continue to assume the mayoral position. But, if he leaves the position for other appointment or demotion, he automatically leaves his chairmanship of the school board. He is merely political appointee.Another secondary school principal stated about the board composition as follows; In the school board one youth and one women league representatives are selected from the community based on their political participation and engagement in the party leagues and affiliate association.

\subsubsection{School Board Representatives Roles in the School Governing Boards}

Table 4 School Board Representatives Responses about their Roles in the School Governing Boards

\begin{tabular}{|l|l|l|l|l|}
\hline No & Variables & Rate & Freq & Percent \\
\hline \multirow{2}{*}{1} & Respondents' Roles in the School Board & Secretary & 3 & $9.7 \%$ \\
\cline { 4 - 5 } & & Member & 27 & $87.1 \%$ \\
\hline
\end{tabular}

As shown in the table 4 above $27(87.1 \%$ ) were found to be members and 3(9.7\%)were school principals who served as secretaries in the education and training boards.

\subsubsection{Establishment of the School Governing Boards}

Table 5 Establishment of the School Governing Boards

\begin{tabular}{|l|l|l|l|}
\hline No & Variables & Freq & Percent \\
\hline 1 & School Initiated & 9 & $29.0 \%$ \\
\hline 2 & Government Initiated & 20 & $64.5 \%$ \\
\hline 3 & Community Initiated & 2 & $6.5 \%$ \\
\hline
\end{tabular}


Regarding the establishment of the education and training boards of the schools, as it is indicated in the table below $20(64.5 \%)$ of the respondents stated that the school boards were organized based on the government directives and jurisdiction. The remaining $9(29.0 \%)$ and 2(6.5\%) responded the board were organized with school and community initiation. In an interview conducted with a secondary school principal of senior secondary school, he stated the following about his school board: Our School board is established based on the exclusive government directives and its composition adheres to the prescribed arrangements outlined by the ministry of education.

\subsubsection{School Board Meeting}

\begin{tabular}{|l|l|l|l|l|}
\hline Table 6 School Board Meeting \\
\hline \multirow{3}{*}{1} & Variables & Rate & Freq & Percent \\
\hline & Frequency of the Board Meeting & Weekly & 2 & $6.5 \%$ \\
\cline { 3 - 5 } & & Monthly & 22 & $71.0 \%$ \\
\cline { 3 - 5 } & & Quarterly & 4 & $12.9 \%$ \\
\cline { 3 - 5 } & & Other & 3 & $9.7 \%$ \\
\hline
\end{tabular}

About the school board meeting sessions, as described in the table above the majority that is $22(71.0 \%)$ of the teacher representatives in the boards responded that the education and training boards conducted their meetings monthly basis.Inaddition,4(12.9\%) and 2(6.5\%) of the respondents stated the boards conducted their meeting quarterly and weekly respectively. The remaining 3(9.7\%) indicated that the schools boards had no regular meeting sessions.

In the interview with senior secondary school principal indicated the following about the frequency of the school board meetings; There is a ministry of education directive that school boards should conduct meetings every two weeks. However, practically our school board meetings are being conducted once in a month. This is due to absence of the members especially those involved in party and political mobilization of the community. This has created unnecessary delay in financial and other key decisions in the school.

\subsubsection{School Budget Reporting}

Table 7 School Budget Reporting

\begin{tabular}{|l|l|l|l|l|}
\hline $\mathbf{N}$ & Variables & Administrative Structure & Freq & Percent \\
\hline$\underline{\mathbf{o}}$ & & & & \\
\hline \multirow{2}{*}{ School budget utilization reported to } & Woreda education department & 24 & $92.3 \%$ \\
\cline { 3 - 5 } & & Parent and Community & 1 & $3.8 \%$ \\
\cline { 3 - 5 } & & Other & 1 & $3.8 \%$ \\
\hline
\end{tabular}

In the study about the school budget utilization report and to whom the reporting were delivered, the majority 24(92.3\%) suggested that the school budget utilizations were regularly reported to the woreda(district) education department. Inline to this, the second round General Education Quality Improvement Project School Grant Directive published jointly by the ministry of education and SNNPR education bureau in 2016 emphasized on issues; annual reporting of the school grant utilization, budget closing time Hamle 1(June7 or 8) transparency and accountability and the allocation of $50 \%$ of the fund to be used for improvement of teaching and learning domain of the school improvement program and posting financial utilization information on the notice board for the school community were indicated clearly.

\section{DISCUSSION}

The major purpose of this study was to investigate the decentralized secondary school governace stte the decentralized secondary school governance structures fiscal decision-making and their implication to school improvement activities in Sidama ZoneTo achieve this end the study was guided by the following basic questions. The study was conducted in a five randomly selected public secondary schools found in the Hawass University Technology site public schools. In the sample secondary schools all of the principals 5(100\%) and all the available teachers and parent representatives in school boards, parent teacher associations were purposively the subjects of this study. Data were gathered through questionnaires from the teachers and deputy principals involved in the school boards and parents interviews was used o collect the data. In addition resource and financial management documents from MOE, SNNPR Education bureau and other related pertinent publications were consulted and interpreted for the study. In the study quantitative data gathered were analyzed using statistical techniques like percentage, mean scores, independent t-test values. Moreover, the qualitative approach was used to compliment the data by interview opened ended questions and document consult. Hence, the results of the data analyzed both qualitatively and quantitatively the major finding were revealed and summarized as follows; 


\subsection{Demographic Background of the Respondents}

Majority $28(90.3 \%)$ of the teachers and deputy principals representatives in the school education and training board were males and the remaining $3(9.7 \%)$ of them were females. The majority of the respondents were bachelor degree holders. Young and senior teachers and deputy principals were incorporated in the study. However, most of the respondents had more than eleven years of work experience.

\subsection{Decentralized Secondary School Governance and Fiscal Decision-making}

The entire teachers and deputy principals indicated that the schools were being governed by established education and training boards. The interviewed principals stated that the school board composition of the members range from 6 to 11 that included the principals as the board secretary and teacher and parent representatives from the parent teachers associations. Besides, the board chair person from the town municipality administrator and youth and women league representatives from the community. Regarding, the school board members understanding of their governance was, $28(90.3 \%)$ of the respondents and mean value 1.9068 indicated ha the members had certain understanding of their schools. However, the interview principals suggested that as the school board chair persons, youth and women league representatives' assignment is based on political party and ethnic affiliation with little emphasis given to their academic preparation and awareness about school operations and some cases members do not come for the regular meeting due their party and political engagements in the community.Concerning board members professional and academic preparation, $21(67.7 \%)$ of the teacher and deputy principals represented in the school board showed that the members have better professional and academic preparations to youth and women league representation in the board were mainly political participation and engagement. The majority of the respondents $120(64.5 \%)$ indicated that the school boards were organized based on the government directives and jurisdiction. Moreover, the interviews revealed that the establishment and composition of the school boards follow the prescribed arrangements given by the ministry of education. Concerning the school board meeting sessions, majority $22(71.8 \%)$ of the teacher representatives replied that the education and training boards conducted their meeting monthly basis. In addition $4(12.9 \%)$ and $2(6.5 \%)$ of the respondents stated that the boards conducted their meeting quarterly and weekly respectively. Regarding the school budget utilization report, the majority $24(92.3 \%)$ of the respondents suggested that the school budget utilization reports are sent to the woreda education department after the school great directive published in 2016 jointly by MOE and SNNPR Educational bureau indicated 50\% of the fund to should be allocated and utilized to the improvement of teaching and learning.

\section{CONCLUSIONS}

Based on the findings of the study, the researcher has come up with the following conclusions; The results implied that the school boards were established with as a top government prescribed directives and government jurisdiction initiative of the government. There was absence of bottom up opportunity for adopting the boards based on the school and community realities.

- There was a rigid board composition. The current trend did not school board composition reflected as more of political assignment than academic structure as the chair person, youth league and women association representatives were mainly select based on political party engagement and ethnic affiliations. In addition their academic preparation and awareness about school operations were not considered in their assignment in the board.

- In the school board the limited number of school level stake holders like deputy principals, department heads, unit leaders and senior teachers affected the board decision making not prioritize on instructional issues and enhancing students achievement rather than administrative matters like construction of fences and toilets ....

- Irregularity of the board meeting sessions hampered the timely decision making process at the school level specially financial decisions were often anticipated delay and purchasing and purchasing and procurement activities in the school took longer time. This is turn affected the students learning and improvement in the student achievement

- The budget utilization reports of the school were often submitted to the woreda (district) education bureau. But there were limited initiative to arrange parents and community general assembly on making the discussion on the budget implementation so as to create accountability of the school system and monitor the resource allocation bought or translated to change in students' academic achievement. Even if there were school resource management directed jointly published by MOE and SNNPR education bureau and issued in 2016 there were often irregularities on the release and endorsement of various types of funds in the secondary schools.

- Though there was school resource management directive issued in 2016 by SNNPR government finance and economic development on who should endorse the grants and how the release of school grants and lock grants neet to be done still there are irregularities among the school in the utilization of different catories of 
funds like bloc and school grants and DFID budget. The discrepancy is demonstrated as some schools PTA, in other schools board and principals were involved in the release of funds.

- The absence of periodical or continuous monitoring of the financial implementation of the schools by the school boards affected not to obtain information how effective and timely funds were utilized in the schools and to take any corrective measures on the progress.

\section{ACKNOWLEDGEMENT}

- First and foremost would like to express my sincere gratitude to Hawasssa University for offering the financial support to accomplish and come up with such this research output.

- In addition, I would like thank all the principals, teachers and parents, woreda or district education bureau experts for their support during my data collection and document gathering stages of the research.

\section{RECOMMENDATIONS}

$>$ The Ministry of Education jointly with SNNPR regional education bureau should re-arrange the school board composition to increase the number of school level stakeholders like deputy principals department heads, unit leaders and senior in the education and training board of the schools. Hence, this facilitate the bottom up trend can create opportunity to govern school with the people who are more experienced and familiar with school level operations.

- The ministry of education jointly with SNNPR regional Education Bureau should reconsider the assignment of school board chair persons, youth league and women association representatives of the board as they are too busy on party and political engagements and hardly avail to govern the boards and monitor the implementation of the decisions of the board. The reassignment of the board membership need to search members from the woreda education bureau, community members on top of that schools level actors who have the necessary academic preparation and time to devote on the governance and monitoring of the day to day operations of the schools.

- The secondary schools should arrange periodical general assembly of the community members and moderate discussions on the school plan and budget implementations. In deed these can promote the accountability of the schools to the community.

- The sidama zone and woreda education bureau should organize workshops on the endorsement, release and implementations of the bloc and school grants, DFID funds and schools' internal relevance and the income and expenditure assignment.

\section{REFERENCES}

[1] Barrera-Osori etal,Fasih,Patrinos and Santibanez(2009).Decentralized Decision-Making in Schools; The Theory and Evidence on School-Based Management.Washington DC.

[2] Behrman, Jere R. and Elizabeth M. King. 2001. Household Schooling Behaviors andDecentralization. Economics of Education Review 20, no. 4: 321-41.

[3] Best and Khan(2005).Research in Education. New Delhi. Offset press.

[4] Brown(1990).Decentralization and School-Based Management..London. The Falmer PressFiske, Edward B. Decentralization of Education: Politics and Consensus. World Bank,,

[5] Washington, D.C.

[6] Hannaway, Carnoy(1993).Decentralization and School Improvement. San Francisco.Jossey-Bass Publishers

[7] Hanushek, Eric A. and Steven G. Rivkin. 2003. Does Public School Competition Affect

[8] Teacher Quality? In The economics of school choice:23-47. Chicago and London:University of Chicago Press.

[9] MoE(2006).Decentralized Management of Education in Ethiopia; A Reference Manual. Addis Ababa.

[10] Transitional Government of Ethiopia (TGE) (1994).Education and Training Policy. Addis Ababa.EMPDA 